UDC 678.664

\author{
V.N. Anisimov, V.V. Anisimov
}

\title{
LINEAR BLOCK-POLYURETHANES WITH OPTIMAL MOLECULAR TOPOLOGY FOR TRIBOTECHNOLOGY
}

\author{
Ukrainian State University of Chemical Technology, Dnipro, Ukraine
}

\begin{abstract}
It is shown that assessment of the properties of linear block-polyurethanes (BPUs) depending on the hardness, which is usually assumed as a basis of their sorting, disregards the features of the molecular structure and the nature of the initial components. A scientifically substantiated approach to the creation of BPU-based materials with an optimal molecular topology for tribological purposes was developed in this study. The effects of molecular weight of linear block-polyurethanes and oligomeric glycols of the methylene series on the deformation, thermophysical and tribological properties were investigated. Thus, the BPUs with the molecular weight of oligoglycols in the range of 500 to 2000 exhibit an efficient combination of high deformation characteristics and sufficient frame hardness. An increase in the degree of crystallinity from $1 \%$ to $20 \%$ results in ordering the structure of the BPUs and, consequently, a growth of elastic modulus from $15 \mathrm{MPa}$ to $225 \mathrm{MPa}$. The use of esters of regular structure contributes to the minimum values of residual elongation and high wear resistance. In addition, the wearing intensity of BPUs with a molecular weight of oligoglycol of about 500 and of regular structures is seven times less than of polyurethanes based on oligoglycol with molecular weight of about 2000. It was also established that BPUs with molecular weights, that correspond to the characteristic viscosity $[\eta]=0.8-$ $1.0 \mathrm{dL} / \mathrm{g}$, have the most optimal structural order, minimum values of wear intensity, and a high heat resistance. The change in the coefficient of friction as a function of the molecular weight is less pronounced, but it reproduces in detail the dependence of the wear intensity on the molecular weight. The conducted research and established dependences can be used to develop the branded range of BPUs.
\end{abstract}

Keywords: block-polyurethane, molecular topology, crystallinity, viscosity, molecular weight.

DOI: $10.32434 / 0321-4095-2020-130-3-20-25$

\section{Introduction}

The complexity of the chemical structure and structural organization of linear block-polyurethanes (BPUs) as well as a large number of factors governing the interrelation of their chemical structure and properties makes them very valuable materials with widely varied ranges of properties. However, this also obstructs the systematization of available data on the relationship of their composition and properties. As a result, the development of compositions of materials based on BPUs, that are optimal for the given conditions of production and exploitation (taking into account the necessity to provide an established complex of properties, availability of raw materials, price, etc.), is performed mainly empirically. Existing conceptions of the relationship between composition and properties of BPUs are often contradictory and even erroneous [1-3].

Due to the above circumstances, one should consider the influence of molecular-mass distribution of macromolecules of the BPU, the chemical structure and the size of elastic blocks when developing noncontradictory views on the relationships between the composition and properties of BPUs.

Until recently, the hardness of BPUs was assumed as a main basis to classify them. However, this property can vary considerably. Recent studies showed that the properties of BPUs depend on the structure and molecular weight of oligoglycol component. The growth of the molecular weight of oligoglycol is accompanied by a decrease in the content of urethane groups, which causes a decrease in the strength and, accordingly, an increase in the

(c) V.N. Anisimov, V.V. Anisimov, 2020 
elasticity and elongation. The value of the optimal molecular weight of oligodiol depends on its nature and is determined by its flexibility: the greater flexibility of an oligoglycol molecule, the smaller molecular weight allows obtaining polyurethanes with optimal properties $[4,5]$.

Saunders and Frish [6] investigated the polyurethane systems based on 1,5naphthylenedisocyanate and oligoethylene glycolladipate of different molecular weight and showed that the properties of elastomers of a molecular weight from 2290 to 3500 vary insignificantly. Significant changes in properties were observed when using oligoglycols with molecular weight of 1385 to 2290 [6,7]. According to the obtained data, the molecular weight of oligoester in the range of 500 to 2000 was considered preferable.

If we compare the polyurethanes of the same structure but with different molecular weight (for example, 20,000 and 80,000), then we can see that their hardness will differ by 2 times (Fig. 1), so the elasticity, physical-mechanical and tribotechnical properties will vary too.

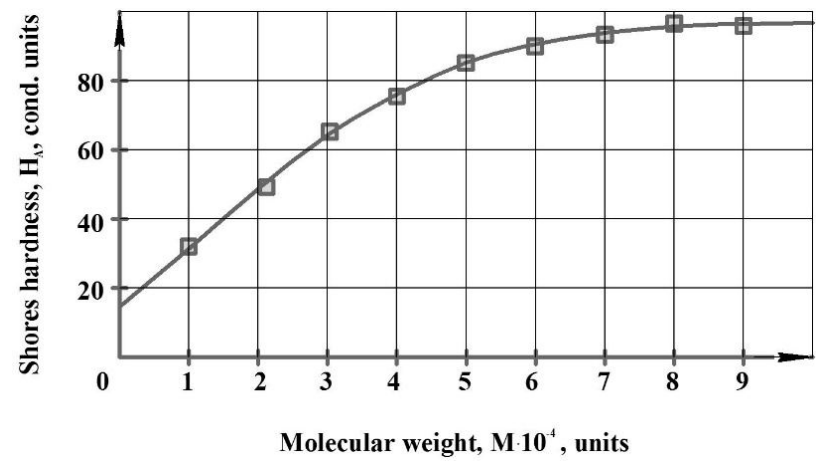

Fig. 1. Impact of molecular weight of BPUs on their hardness

It can be concluded that the estimation of wear resistance of BPUs without taking into consideration their molecular structure is inaccurate. Hence, it is important to establish the relationship between the structure and properties of polyurethanes taking into account their chemical structure.

The purpose of this work was to study the effect of the molecular weight of linear block-polyurethanes and oligomeric glycols of different nature (synthesized from adipic acid and methylene glycols) on the deformation-strength and thermophysical characteristics of BPUs.

\section{Experimental}

Linear block-polyurethanes with different molecular structure were chosen as objects in this study. As oligomeric glycols (OG), we used esters of regular structure: oligobutylene glycolladipinate with molecular weight of $\sim 500$ and $\sim 2000$ (designated as $\mathrm{OBGA}_{500}$ and $\mathrm{OBGA}_{2000}$, respectively). In addition, esters with variable identity period, oligoethylene glycoladipinate with a molecular weight of $\sim 2000$ (designated as $\mathrm{OEGA}_{2000}$ ) were studied. Urethane groups were formed from 4,4'-diphenylmethane diisocyanate (MDI). Low molecular weight glycol, 1,4-butanediol (butylene glycol) (BD), was introduced to obtain the block structure of BPUs.

The samples were prepared under laboratory conditions by one-step synthesis at the following mass ratio: $\mathrm{NCO}: \mathrm{OH}=1: 1$.

The molecular mass of BPU was varied by introducing some multifunctional chain terminating agents into the initial mixture. The molecular weight (M) was controlled by measuring the characteristic viscosity $[\eta]$ of the BPU solutions in dimethylformamide at the temperature of $303 \mathrm{~K}$. The dependence of $[\eta]$ on $M$ can be analytically described by the following power-law Mark-Houvink equation:

$$
[\eta]=1.2 \cdot 10^{4} \cdot \mathrm{M}^{0.81} \text {. }
$$

To determine the elasticity modulus at tension $\left(E_{p}\right)$, conditional tensile strength $\left(f_{p}\right)$, value of relative elongation $\left(\varepsilon_{\mathrm{p}}\right)$, residual elongation $(\varepsilon)$, Shore hardness number $\left(\mathrm{H}_{\mathrm{A}}\right)$ and Vicat softening temperature $\left(T_{p}\right)$, standard methods of physical and mechanical tests were used.

The studies of the wearing intensity and the coefficient of friction for BPUs were carried out using a disk friction machine with a «disk-finger sample» scheme at the speed of $0.4 \mathrm{~m} / \mathrm{s}$ for a partial loading $0.2 \mathrm{MPa}$.

Structural analyzer «Epiquant» was used to study the topography of friction surfaces and the nature of their destruction.

$X$-ray structural studies of the phase composition of the developed materials were performed by the DRON-2 installation. The X-ray diffraction analysis was conducted in copper $\left(\mathrm{CuK}_{\alpha}\right)$ radiation using a crystal-monochromator under the following operating modes: the voltage of $20 \mathrm{kV}$, the amperage of $10 \mathrm{~mA}$ and the measurement limit of 1000. The diffraction peaks were recorded in the range of reflection angles of 5 to $150^{\circ}$. The double angles were determined from the position of the peak of the diffraction maximum. Then, the distance between the atomic (molecular) layers in the volume of amorphous polymers $d(\mathrm{~nm})$ was determined by using the Wolf-Bragg equation from the reflection angle of interplanar distances in the crystalline lattice of amorphous crystalline polyurethanes [1]. 
Conclusions about the changes in the structure of the BPUs were drawn based on the intensities of the peaks in the indicatrices of $\mathrm{X}$-ray scattering.

The degree of crystallinity, $\mathrm{C}_{\mathrm{c}}$, was determined by the Matthew method [1] as the ratio of the surface under the crystalline reflexes $\left(S_{k}\right)$ in the indicatrix to the total surface under the coherent scattering curve $\left(\mathrm{S}_{\mathrm{k}}+\mathrm{S}_{\mathrm{a}}\right)$.

\section{Results and discussion}

First, the properties of linear blockpolyurethanes based on esters of a regular structure and different molecular weights $\left(\mathrm{OBGA}_{500}\right.$ and $\mathrm{OBGA}_{2000}$ ) were studied. In addition, we investigated the characteristics of linear block-polyurethanes with a variable period of identity $\left(\mathrm{OEGA}_{2000}\right)$ at a minimum content of hard blocks, i.e. when OG:BD:MDI=1:0:1. The obtained results are summarized in Table 1.

Table 1

Properties of BPUs based on esters of different structure with a minimum content of hard blocks

\begin{tabular}{|c|c|c|c|}
\hline \multirow{2}{*}{ Parameter } & \multicolumn{3}{|c|}{ BPU based on oligoesters } \\
\hline & $\mathrm{OBGA}_{2000}$ & $\mathrm{OEGA}_{2000}$ & $\mathrm{OBGA}_{500}$ \\
\hline $\begin{array}{l}\text { Shore hardness }\left(\mathrm{H}_{\mathrm{A}}\right) \text {, } \\
\text { units }\end{array}$ & 60 & 30 & 87 \\
\hline $\begin{array}{l}\text { Elasticity modulus at } \\
\text { tension }\left(\mathrm{E}_{\mathrm{p}}\right), \mathrm{MPa}\end{array}$ & 225 & 70 & 15 \\
\hline $\begin{array}{l}\text { Conditional stretching } \\
\text { strength }\left(\mathrm{f}_{\mathrm{p}}\right), \mathrm{MPa}\end{array}$ & 70 & 25 & 63 \\
\hline $\begin{array}{l}\text { Relative elongation at } \\
\text { rupture }\left(\varepsilon_{\mathrm{p}}\right), \%\end{array}$ & 500 & 530 & 500 \\
\hline $\begin{array}{l}\text { Residual elongation } \\
(\varepsilon), \%\end{array}$ & 5 & 220 & 5 \\
\hline $\begin{array}{l}\text { Melt temperature (T), } \\
{ }^{0} \mathrm{C}\end{array}$ & 58 & 77 & 48 \\
\hline $\begin{array}{l}\text { Degree of } \\
\text { crystallinity } C_{K}, \%\end{array}$ & 20 & 9 & 1 \\
\hline $\begin{array}{l}\text { Wearing intensity", } \\
\mathrm{I} \cdot 10^{4}, \mathrm{~g} / \mathrm{km}\end{array}$ & 180 & 800 & 25 \\
\hline
\end{tabular}

Note: * - friction without lubrication at $\mathrm{P}=0.1 \mathrm{MPa}$ and $\mathrm{V}=0.2$ $\mathrm{m} / \mathrm{s}$.

An increase in the degree of crystallinity from $1 \%$ to $20 \%$ contributes to the ordering of the BPUS structure and, consequently, the growth of the elasticity modulus from $15 \mathrm{MPa}$ to $225 \mathrm{MPa}$. The use of regular structure esters allows minimizing the residual elongation and provides a high wear resistance. In addition, BPUs with OG having molecular weight of $\sim 500$ and with regular structure show the wear intensity that is 7 times less than that of polyurethanes based on OG with molecular weight of $\sim 2000$.

Thus, the data presented in Table 1 indicate that the consideration of only a hardness value is insufficient to evaluate the properties of a BPU. It is necessary to take into account the orderliness and molecular weight of oligoglycols, which are part of their composition.

The influence of the molecular weight of linear block-polyurethanes on their properties is presented below. It was established that the dependences of the wearing intensity on the characteristic viscosity revealed an extremum for all studied systems. There are three characteristic segments in the obtained dependences (Fig. 2). Polyurethanes of the first area $([\eta]=0.4-0.8 \mathrm{dL} / \mathrm{g})$ are characterized by large values of the wearing intensity.

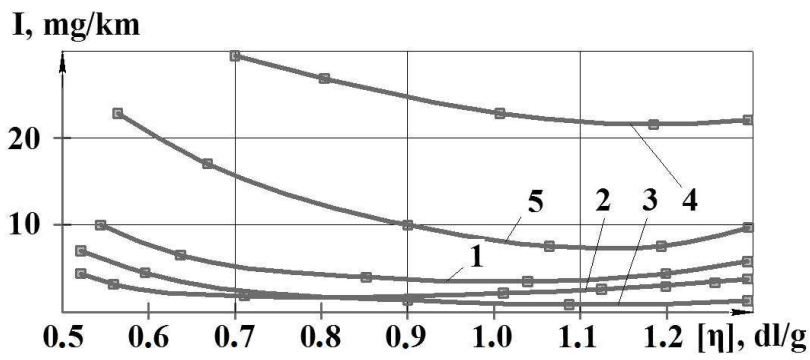

Fig. 2. Dependences of the wear intensity of linear block-polyurethanes on the characteristic viscosity $(\mathrm{V}=0.4 \mathrm{~m} / \mathrm{s}, \mathrm{P}=0.2 \mathrm{MPa}): 1-\mathrm{OBGA}_{500}: \mathrm{BD}: \mathrm{MDI}=1.0: 0.5: 1.5$;

$$
\begin{gathered}
2-\mathrm{OBGA}_{500}: \mathrm{BD}: \mathrm{MDI}=1.0: 1.5: 2.5 \\
3-\mathrm{OBGA}_{500}: \mathrm{BD}: \mathrm{MDI}=1.0: 3.0: 4.0 \\
4-\mathrm{OEGA}_{2000}: \mathrm{BD}: \mathrm{MDI}=1.0: 0.5: 1.5 \\
5-\mathrm{OEGA}_{2000}: \mathrm{BD}: \mathrm{MDI}=1.0: 4.0: 5.0
\end{gathered}
$$

With an increase in [ $\eta$ ] from 0.4 to $0.8 \mathrm{dL} / \mathrm{g}$ (the molecular weight reaches the values of 50,000), a rapid decrease in the intensity of wear was observed. There is an increase in the physical and mechanical characteristics of polyurethanes in this interval $[7,8]$. Deep debris traces were revealed when studying the friction surfaces of these BPUs by optical microscopy (Fig. 3,a). A mechanism of wear due to the formation of «rollers» is preferable, and the products of wear in this case look like large particles and flakes. This mechanism is especially typical of materials with a minimum content of butanediol $(0.5 \mathrm{~mol})$.

With an increase in molecular weight, the intensity of materials wear is significantly stabilized and, accordingly, a second area in the plots appears at the characteristic viscosity in the range of 0.8 to $1.0 \mathrm{dL} / \mathrm{g}$ (Fig. 2) that corresponds to the molecular weight within the range of 50,000 to 70,000 . It was established that fatigue mechanism of wearing is 


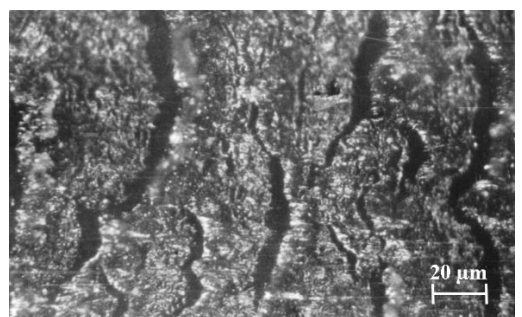

a

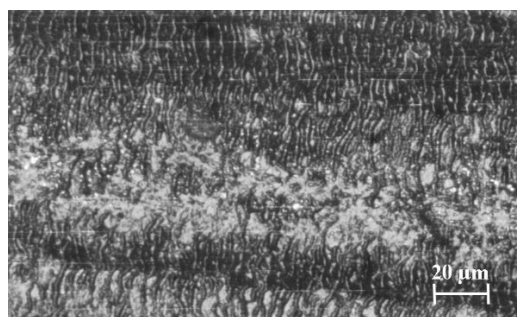

b

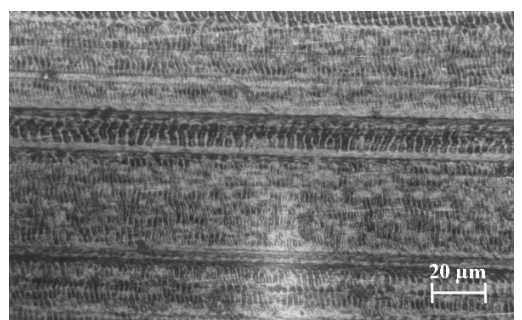

Fig. 3. Microphotographs of the friction surfaces of BPU based on $\mathrm{OBGA}_{500}$ at different values of the characteristic viscosity (friction without lubrication): $\mathrm{a}-[\eta]=0.4-0.8 \mathrm{dL} / \mathrm{g} ; \mathrm{b}-[\eta]=0.8-1.0 \mathrm{dL} / \mathrm{g} ; \mathrm{c}-[\eta]=1.0-1.5 \mathrm{dL} / \mathrm{g}$
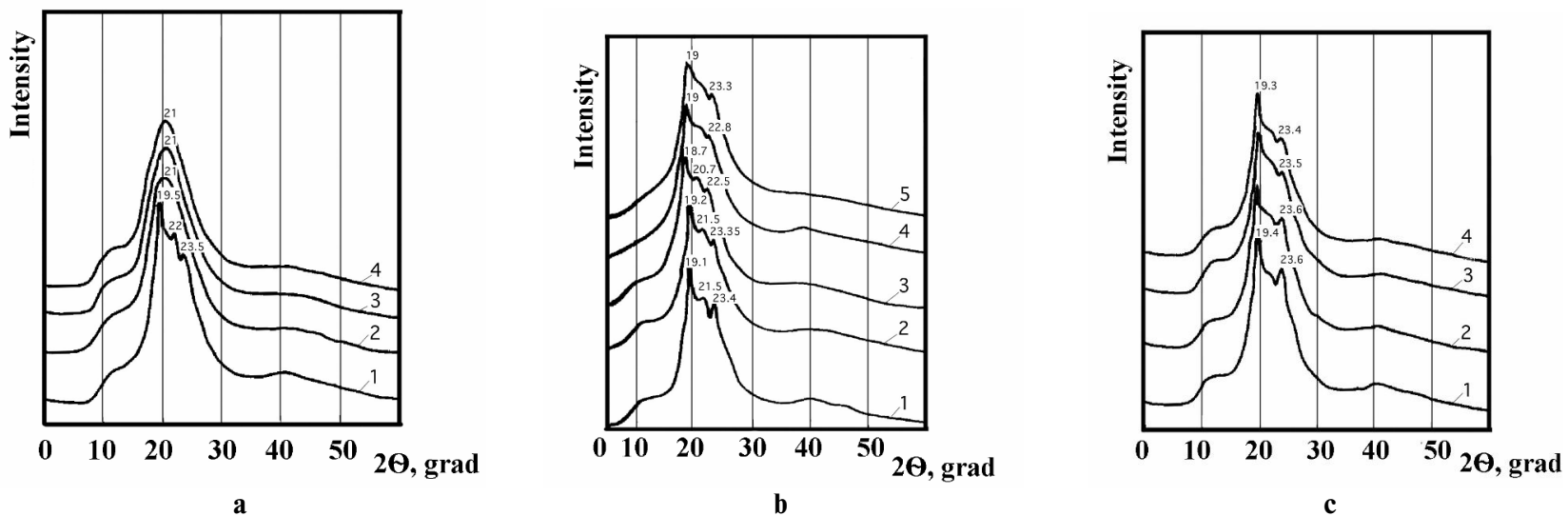

Fig. 4. X-ray scattering indicatrices for polyurethanes based on $\mathrm{OBGA}_{500}$ with different molecular weight and butanediol content: $1 \mathrm{a}-[\eta]=0.52 \mathrm{dL} / \mathrm{g} ; 2 \mathrm{a}-[\eta]=0.87 \mathrm{dL} / \mathrm{g} ; 3 \mathrm{a}-[\eta]=1.2 \mathrm{dL} / \mathrm{g} ; 4 \mathrm{a}-[\eta]=1.48 \mathrm{dL} / \mathrm{g} ; 1 \mathrm{~b}-[\eta]=0.42 \mathrm{dL} / \mathrm{g} ; 2 \mathrm{~b}-[\eta]=0.66 \mathrm{dL} / \mathrm{g} ;$

$3 \mathrm{~b}-[\eta]=1.06 \mathrm{dL} / \mathrm{g} ; 4 \mathrm{~b}-[\eta]=1.23 \mathrm{dL} / \mathrm{g} ; 5 \mathrm{~b}-$ insoluble; $1 \mathrm{c}-[\eta]=0.6 \mathrm{dL} / \mathrm{g} ; 2 \mathrm{c}-[\eta]=0.84 \mathrm{dL} / \mathrm{g} ; 3 \mathrm{c}-[\eta]=1.52 \mathrm{dL} / \mathrm{g}$; $4 \mathrm{c}-$ insoluble

preferred in this case (Fig. 3), and the wear products have a form of finely dispersed powder. Blockcopolyurethanes with a viscosity $[\eta]=0.8-1.0 \mathrm{dL} / \mathrm{g}$ have a maximum wear resistance.

The third area includes materials, for which characteristic viscosity exceeds $1.0 \mathrm{dL} / \mathrm{g}(\mathrm{M}>70,000)$. In this case, the intensity of wear does not change with increasing $[\eta]$ or insignificantly increases (Fig. 2). Optical observations showed that the friction surfaces contained traces of microcutting in the form of furrows, which were located along the slip direction (Fig. 3,b). That indicated a predominantly abrasive nature of wear. Despite the fact that the intensity of wear remained at a satisfactory level, a decrease in such important physical-mechanical parameters as the value of relative elongation at rupture, the resistance to bending, and the conditional stress during elongation was established [7]. Hence, it is not advisable to consider the synthesis of polyurethanes with molecular weights of more than 70,000 units and their application for epy production of wear-resistant parts of machines and aggregates.

The change in coefficient of friction with molecular weight is less expressed, but it repeats in detail the dependence of the wear intensity on the value of molecular weight.

The analysis of X-ray patterns (Figs. 4 and 5) showed that the expressed formation of crystallines is noticeable in the structure of polyurethanes at the angles of scattering in the range of $2 \theta=19-24^{\circ}$ with an increase in the characteristic viscosity up to $0.8^{-}$ $1.0 \mathrm{dL} / \mathrm{g}$, the parameters of the crystal lattice being
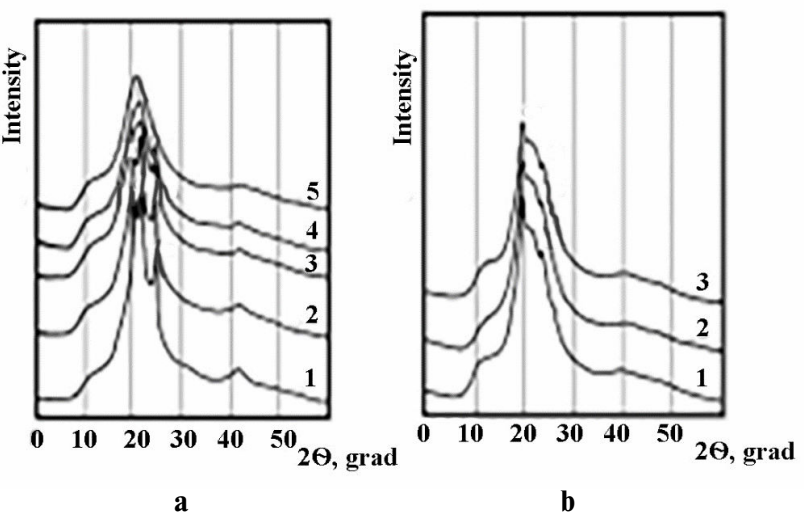

b

Fig. 5. X-ray scattering indicatrices for polyurethanes based on OEGA $_{2000}$ with different molecular weight and butanediol content: $1 \mathrm{a}-[\eta]=0.61 \mathrm{dL} / \mathrm{g} ; 2 \mathrm{a}-[\eta]=0.89 \mathrm{dL} / \mathrm{g}$;

$3 \mathrm{a}-[\eta]=1.2 \mathrm{dL} / \mathrm{g} ; 4 \mathrm{a}-[\eta]=1.46 \mathrm{dL} / \mathrm{g} ; 1 \mathrm{~b}-[\eta]=0.58 \mathrm{dL} / \mathrm{g}$; $2 \mathrm{~b}-[\eta]=0.89 \mathrm{dL} / \mathrm{g} ; 3 \mathrm{~b}-$ insoluble, $5 \mathrm{a}-$ insoluble 
Table 2

Structure and properties of BPUs based on $\mathrm{OBGA}_{500}$ of different characteristic viscosity

\begin{tabular}{|c|c|c|c|c|c|c|}
\hline \multirow{2}{*}{ Parameter } & \multirow{2}{*}{$\begin{array}{l}\text { Ratio of initial } \\
\text { components }\end{array}$} & \multicolumn{5}{|c|}{ 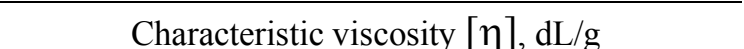 } \\
\hline & & 0.4 & 0.8 & 1.0 & 1.2 & insoluble \\
\hline \multirow{3}{*}{ Upper limit of the softening temperature, $K$} & $1: 0.5: 1,5$ & 321 & 343 & 349 & 335 & 310 \\
\hline & $1: 1.5: 2,5$ & 402 & 415 & 430 & 418 & 410 \\
\hline & $1: 3.0: 4.0$ & 377 & 418 & 458 & 461 & 475 \\
\hline \multirow{3}{*}{$\begin{array}{l}\text { Relation of planes of crystalline and } \\
\text { amorphous regions } \mathrm{S}_{\mathrm{K}} / \mathrm{S}_{\mathrm{a}}, \%\end{array}$} & $1: 0.5: 1.5$ & 6 & - & - & - & - \\
\hline & $1: 1.5: 2.5$ & 9 & 4.2 & 4.3 & 3.0 & 5.8 \\
\hline & $1: 3.0: 4.0$ & 12 & 11 & 10.5 & 9 & 5 \\
\hline \multirow{3}{*}{$\begin{array}{l}\text { Value of the double angle of reflection } 2 \theta \text {, } \\
\text { deg }\end{array}$} & $1: 0.5: 1.5$ & $\begin{array}{l}19.5 \\
22.0 \\
23.5\end{array}$ & - & - & - & - \\
\hline & $1: 1.5: 2.5$ & $\begin{array}{l}19.1 \\
21.5 \\
23.4\end{array}$ & $\begin{array}{l}19.2 \\
21.5 \\
23.35\end{array}$ & $\begin{array}{l}18.7 \\
20.7 \\
22.5\end{array}$ & $\begin{array}{c}19.0 \\
22.3 \\
-\end{array}$ & $\begin{array}{c}19.0 \\
23.3 \\
-\end{array}$ \\
\hline & $1: 3.0: 4.0$ & $\begin{array}{r}- \\
19.4 \\
23.6\end{array}$ & $\begin{array}{c}- \\
19.4 \\
23.6\end{array}$ & $\begin{array}{c}- \\
19.4 \\
23.6\end{array}$ & $\begin{array}{c}- \\
19.4 \\
23.5\end{array}$ & $\begin{array}{c}- \\
19.3 \\
23.4\end{array}$ \\
\hline \multirow{3}{*}{$\begin{array}{l}\text { Interplanar distance (crystal lattice } \\
\text { parameter), } \mathrm{nm}\end{array}$} & $1: 0.5: 1.5$ & $\begin{array}{c}0.458 \\
0.42 \\
0.377 \\
\end{array}$ & - & - & - & - \\
\hline & $1: 1.5: 2.5$ & $\begin{array}{c}0.46 \\
0.412 \\
0.38 \\
\end{array}$ & $\begin{array}{c}0.46 \\
0.412 \\
0.38 \\
\end{array}$ & $\begin{array}{c}0.48 \\
0.425 \\
0.39 \\
\end{array}$ & $\begin{array}{c}0.46 \\
0.38 \\
-\end{array}$ & $\begin{array}{c}0.46 \\
0.38 \\
-\end{array}$ \\
\hline & 1:3.0:4.0 & $\begin{array}{l}0.457 \\
0.376 \\
\end{array}$ & $\begin{array}{l}0.459 \\
0.379 \\
\end{array}$ & $\begin{array}{l}0.459 \\
0.379 \\
\end{array}$ & $\begin{array}{l}0.459 \\
0.379 \\
\end{array}$ & $\begin{array}{l}0.459 \\
0.379 \\
\end{array}$ \\
\hline
\end{tabular}

0.36-0.48 nm (Table 2). A further increase in the molecular weight causes the disordering of the structure, which is confirmed by the presence of a wide amorphous halo with a maximum at $2 \theta=20^{\circ}$.

As follows from the analysis of thermograms, the heat resistance of the investigated polyurethanes also depends on the molecular weight of the polymer (Table 2). With increasing molecular weight $([\eta]=0.8-1.0 \mathrm{dL} / \mathrm{g})$, a noticeably sharp increase in the softening temperature is observed. For molecular weights corresponding to $[\eta]>1.0 \mathrm{dL} / \mathrm{g}$, the heat resistance of polyurethanes is reduced. We detected an increase in the heat resistance in the whole interval of [h] only for the BPUs based on $\mathrm{OBGA}_{500}$ with the content of the BD of about 3.0 moles and for BPUs based on $\mathrm{OEGA}_{2000}$ with the content of the $\mathrm{BD}$ of about 0.5 moles. This is due to the peculiarities of the formation of the BPUs structure at a given ratio of components.

Thus, from the point of view of tribotechnical characteristics, an optimal value of molecular weight of linear block-polyurethanes is close to $[\eta]=0.8-$ $1.0 \mathrm{dL} / \mathrm{g}$.

\section{Conclusions}

1. It was established that the assessment of BPUs properties using only their hardness, which is currently generally accepted, is inaccurate and greatly complicates the systematization of the available data on the relationships between their composition and properties. So, if we compare polyurethanes of the same structure, but with different molecular weights (for example, 20,000 and 80,000), then their hardness will differ by two times; hence elasticity, physicalmechanical and tribological characteristics will be different.

2. In accordance with the obtained data, it is necessary to take into account the ordering and molecular weight of oligoglycols, which was considered preferable in the range of 500-2000.

3. Linear block-polyurethanes of molecular weight corresponding to the characteristic viscosity $[\eta]=0.8-1.0 \mathrm{dL} / \mathrm{g}$ reveal the most optimal structural order, the minimum values of wear rate and a high heat resistance.

4. The obtained results can be assumed as a scientific basis for the development of branded ranges of BPUs. 


\section{REFERENCES}

1. Shtompel V.I., Kercha Y.Y. Struktura lineinykh poliuretanov. - K.: Naukova dumka, 2008. - 247 p.

2. Danylchenko D.O. Horolskyj M.S., Danylchenko O.P. Ogl'yad fizyko-mekhanichnykh vlastyvostei poliuretanovykh elastomeriv i perspektyvnykh galuzei ikh vykorystannya // Khimichna promyslovist' Ukrainy. - 2001. - No. 3. - P.56-58.

3. Skakun J.V., Nizelskyj J.M. Termoplastychni poliuretany: budova, vlastyvosti, vykorystannya // Polimernyj zhurnal. - 2007. - Vol.29. - No. 1. - P.3-9.

4. Lipatov Yu.S., Kercha Yu.Yu., Sergeeva L.I. Struktura i svoistva poliuretanov. K.: Naukova dumka, 1970. -280 p.

5. Anisimov V.N. The principle of producing linear blockpolyurethane-composites of improved wear resistance // East. Eur. Sci. J. - 2013. - No. 5. - P.107-113.

6. Saunders J.H., Frish K.K. Khimiya poliuretanov. - M.: Khimiya, 1968. - 470 p.

7. Byuist J.M. Kompozitsionnye materialy na osnove poliuretanov. - M.: Khimiya, 1978. -238 p.

8. Anisimov V.N., Semenets A.A. Development of triboengineering composite materials based on thermoplastic polyurethanes // J. Frict. Wear. - 2010. - Vol.31. - No. 3. P.208-213.

\section{ЛІНІЙНІ БЛОК-ПОЛІУРЕТАНИ 3 ОПТИМАЛЬНОО МОЛЕКУЛЯРНОЮ ТОПОЛОГЕЮ ДЛЯ ТРИБОТЕХНІКИ}

\section{В.М. Анісімов, В.В. Анісімов}

Показана необ'єктивність оцінювання властивостей лінійних блок-поліуретанів (БПУ) в залежнності від твердості, яка, як правило, закладена в основу їх маркування і не враховує особливостей молекулярної будови і природи вихідних компонентів. Розроблено науково-обгрунтований підхід до створення матеріалів для триботехніки на основі БПУ з оптимальною молекулярною топологією. Досліджено вплив молекулярної маси лінійних блок-поліуретанів і олігомерних гликолів метиленового ряду на деформаційно-міцнісні, теплофізичні і триботехнічні характеристики. Так, БПУ з молекулярною масою олігогліколів в діапазоні 500-2000 мають раціональне поєднання високих деформаційних характеристик і достатньої каркасної жорсткості. Збільшення ступеня кристалічності з 1\% до 20\% сприяє упорядкуванню структури БПУ $i$, отже, зростанню модуля пружності з 15 МПа до 225 МПа. Застосування естерів регулярної будови сприяє мінімальним значенням залишкового подовження і високої зносостійкості. Крім того, БПУ молекулярної масою ОГ 500 регулярної будови мають в 7 разів меншу інтенсивність зношування у порівнянні з поліуретанами на основі ОГ 2000. Також встановлено, що БПУ з молекулярної масою, що відповідає показнику в язкості $[\eta]=0,8-1,0$ дл/2, мають найбільщ оптимальну структурну впорядкованість, мінімальні значення інтенсивності зношування та високу теплостійкість. Зміна коефіцієнта тертя від молекулярної маси носить менш виражений характер, але повторює в деталях залежність інтенсивності зношування від молекулярної маси. Проведені дослідження і встановлені закономірності можуть служити науковою основою при розробці марочного асортименту БПУ.

Ключові слова: блок-поліуретан, молекулярна топологія, кристалічність, в’язкість, молекулярна маса.

\section{LINEAR BLOCK-POLYURETHANES WITH OPTIMAL} MOLECULAR TOPOLOGY FOR TRIBOTECHNOLOGY

\author{
V.N. Anisimov, V.V. Anisimov *
}

Ukrainian State University of Chemical Technology, Dnipro, Ukraine

\section{* e-mail: wwwovilon@gmail.com}

It is shown that assessment of the properties of linear blockpolyurethanes (BPUs) depending on the hardness, which is usually assumed as a basis of their sorting, disregards the features of the molecular structure and the nature of the initial components. A scientifically substantiated approach to the creation of BPU-based materials with an optimal molecular topology for tribological purposes was developed in this study. The effects of molecular weight of linear block-polyurethanes and oligomeric glycols of the methylene series on the deformation, thermophysical and tribological properties were investigated. Thus, the BPUs with the molecular weight of oligoglycols in the range of 500 to 2000 exhibit an efficient combination of high deformation characteristics and sufficient frame hardness. An increase in the degree of crystallinity from $1 \%$ to $20 \%$ results in ordering the structure of the BPUs and, consequently, a growth of elastic modulus from $15 \mathrm{MPa}$ to $225 \mathrm{MPa}$. The use of esters of regular structure contributes to the minimum values of residual elongation and high wear resistance. In addition, the wearing intensity of BPUs with a molecular weight of oligoglycol of about 500 and of regular structures is seven times less than of polyurethanes based on oligoglycol with molecular weight of about 2000. It was also established that BPUs with molecular weights, that correspond to the characteristic viscosity $[\eta]=0.8-1.0 \mathrm{dL} / \mathrm{g}$, have the most optimal structural order, minimum values of wear intensity, and a high heat resistance. The change in the coefficient of friction as a function of the molecular weight is less pronounced, but it reproduces in detail the dependence of the wear intensity on the molecular weight. The conducted research and established dependences can be used to develop the branded range of BPUs.

Keywords: block-polyurethane; molecular topology; crystallinity; viscosity; molecular weight.

\section{REFERENCES}

1. Shtompel V.I., Kercha Y.Y., Struktura lineinykh poliuretanov [Structure of linear polyurethanes]. Naukova Dumka, Kyiv, 2008. 247 p. (in Russian).

2. Danylchenko D.O., Horolskyj M.S., Danylchenko O.P. Oglyad fizyko-mekhanichnykh vlastyvostei poliuretanovykh elastomeriv i perspektyvnykh galuzei yikh vykorystannya [A review of physical-mechanical properties of polyurethanes and promising fields of their usage]. Khimichna Promyslovist Ukrainy, 2001, no. 3, pp. 56-58. (in Ukrainian).

3. Skakun J.V., Nizelskyj J.M. Termoplastychni poliuretany: budova, vlastyvosti, vykorystannya [Thermoplastic polyurethanes: structure, properties and application]. Polimernyj Zhurnal, 2007, vol. 2, no. 1, pp. 3-9. (in Ukrainian).

4. Lipatov Yu.S., Kercha Yu.Yu., Sergeeva L.I., Struktura i svoistva poliuretanov [Structure and properties of polyurethanes]. Naukova Dumka, Kyiv, 1970. 280 p. (in Russian).

5. Anisimov V.N. The principle of producing linear blockpolyurethane-composites of improved wear resistance. Eastern European Scientific Journal, 2013, no. 5, pp. 107-113.

6. Saunders J.H., Frish K.K., Khimiya poliuretanov [Chemistry of polyurethanes]. Khimiya, Moscow, 1968. 470 p. (in Russian).

7. Byuist J.M., Kompozitsionnye materialy na osnove poliuretanov [Composite materials based on polyurethanes]. Khimiya, Moscow, 1978. 238 p. (in Russian).

8. Semenets A.A., Anisimov V.N. Development of triboengineering composite materials based on thermoplastic polyurethanes. Journal of Friction and Wear, 2010, vol. 31, pp. 208-213. 